\title{
The Use of Cassava, Sweet Potato and Cocoyam, and Their By-Products by Non - Ruminants
}

\author{
D. F. Apata ${ }^{1, *}$, T. O. Babalola ${ }^{2}$ \\ ${ }^{1}$ Department of Animal Production, University of Ilorin, Nigeria \\ ${ }^{2}$ Dep artment of Animal Science Landmark University, Omu-Aran, Nigeria
}

\begin{abstract}
As the search for alternative sources of energy for non ruminants continues, this review was undertaken to examine the potential value of cassava (Manihot utilissima Pohl.), sweet potato (Ipomea batatas Poir.), cocoyam (Xanthosoma sagittifolium Schott.) and their by-products as dietary supplements for non ruminants. Studies on these roots and tubers showed that, on a dry-weight basis, contained $2.0-7.9 \%$ crude protein, $0.3-3.1 \%$ crude fib re and $72.4-77.9 \%$ starch. The practical use of these roots and tubers in non ruminant feeds is generally low. This level of utilization is attributed to the low protein and dry matter and the potentially to xic cyanogenic glycosides in fresh cassava and irritating substance in cocoyam. Processing techniques such as fermentation, soaking, boiling, ensiling and sun-drying are adopted to remove the deleterious substances, and effects on animals. The comparable performance of pigs and poultry fed vary ing levels of roots and tubers and their by-products with those ma intained on maize showed that they can be used as substitutes in non-ru minants diets at certain levels without detrimental effects. To achieve increase in the use of these root crops and their by-products for maize replacement in intensive non-ruminant production systems, adequate protein supplementation and proper processing are essential.
\end{abstract}

Keywords By-Products, Cassava, Cocoyam, Non-Ruminants, Sweet Potato

\section{Introduction}

The greatest proportional cost in livestock production is expended on feeding, with the exception of ruminants whose feed is based on pasture. In non-ruminant animals such as pigs and poultry, feed ingredients represent 65 to $70 \%$ of the total cost in an intensive production system in Nigeria as in many developing countries[1]. Energy source constitutes between 45 and 60 percent of finished feeds for these animals[2], and at present, maize is the commonly used source of energy in livestock feeds[3]. The increasing pressure on the use of maize by human population and livestock feed millers coupled with the cost of maize which fluctuates with the time of the year, thus making the cereal grain to be either scarce or expensive, stimulate the use of alternative sources of energy that are locally available, particularly the starchy roots and tubers that abound in many areas of humid tropics. In addition, their by products such as peels, vines and leaves are non competitive feed materials that can be developed as components of poultry and pig feeds. Although roots and tubers are cheap sources of energy, the extent of their practical use in non ruminant feeding has been

* Corresponding author:

dfapataunilorin@yahoo.com (D. F. Apata)

Published online at http://journal.sapub.org/food

Copyright (C) 2012 Scientific \& Academic Publishing. All Rights Reserved limited. For example in Nigeria, 5\% of total cassava production is used as feed. The presence of toxic cyanogenic glycosides and other undesirable substances, dustiness of the dried products, mouldiness during processing and the high fibre of the peel account for the low utilization in non ruminant production. $[4,5]$.

Recently, emphasis has been placed on the expanded programme of cassava, sweet potato and cocoyam cultivation, and many high yielding variet ies of cassava have developed and released through the improvement efforts of International Institute of Tropical Agriculture (IITA) and other collaborating institutions, suggests that production in excess of direct human consumption will become available for feeding farm animals in Nigeria. This paper reviews the potential value and constraints to increase use of these roots and tubers and their by-products as dietary supplements for non ruminants and fish. Additionally, this paper refers to ways that could increase the use of these feed sources.

\section{Production and Nutritional Value of the Roots and Tubers}

Cassava, sweet potato and cocoyam are cultivated as staple food crops. They are efficient in producing cheap food energy. More than 228 million tons of cassava was produced worldwide in 2007, of which Africa accounted for $52 \%$. In 2007, Nigeria produced 46 million tons making it the world's 
largest producer (Table 1). The yields of sweet potato was 15-20 tonnes per hectare and cocoyam give 25-30 tonnes per hectare of corns depending on planting density.

Table 1. World cassava production (-000 tonnes)

\begin{tabular}{lcccc}
\hline & \multicolumn{4}{c}{ Year } \\
\cline { 2 - 5 } & 2006 & 2007 & $2008^{*}$ & $2009^{* *}$ \\
\hline Nigeria & 45721 & 34410 & 42770 & 45000 \\
Congo, Dem. Rep. of & 14989 & 15004 & 15020 & 15036 \\
Ghana & 9638 & 9650 & 9700 & 10000 \\
Angola & 8810 & 8800 & 8900 & 9000 \\
Mozambique & 6765 & 5039 & 8400 & 9200 \\
Tanzania, United & 6158 & 6600 & 6700 & 6500 \\
Rep. of & 4926 & 4456 & 4942 & 4500 \\
Uganda & 2832 & 3239 & 3700 & 4000 \\
Malawi & 2359 & 2400 & 2405 & 2000 \\
Madagascar & 15251 & 15354 & 15923 & 16233 \\
Other Africa & 117 & 104 & 118 & 121469 \\
Africa & 449 & 952 & 461 & 36606 \\
Latin America & 36311 & 36429 & 37024 & 36715 \\
Asia & 70465 & 75882 & 77631 & 83715 \\
World & 224 & 217 & 233 & 242069 \\
\hline
\end{tabular}

* Estimate

** Forecast

Source:[6]

The roots, tubers and their by-products are valuable sources of nutrients (Table 2). They share a number of nutritional characteristics that constitute serious limitations for their practical use in poultry, pig and fish feeding, if they are compared with the cereals which are feed ingredients. The most important of these limitations are as follows:

(i) All of them are succulent materials with low content of dry matter (25-32 percent). This makes the preservation, transport costs and general handling more difficult.

(ii) All of them have starch being the major component with low protein (2.7-7.9 percent) that obviously needs adequate protein supplementation.

(iii) Root and tuber by-products (peels, leaves and vines) are high in crude fibre $(12.1-16.0 \%)$. W ith such high level, the use of appropriate exogenous enzymes to degrade the fibre is required for improved utilization by non ruminants[7].

(iv) Some of them contain toxic/anti-nutritional factors (Table 3) such as cyanogenic glycosides (linamarin and lotaustralin) in cassava which cause bitter taste and reduce palatability of the roots. Cocoyam contains irritating/acridity substance that causes burning sensation. The undesirable substances must be eliminated through some kind of processing such as fermentation, grating, boiling or sun-drying before being fed to animals to reduce the risk of toxicity.

(v) Microbial contamination due to high moisture content. Sun-drying of these materials in a humid environment, especially during a bad weather, results in the proliferation of microbial organisms in the feed materials. It is imperative to have driers and silos to reduce deteriorative changes and contamination.

(vi) Dustiness of the dried roots and tubers flour can cause irritation of the respiratory tract unless feed is palletized or palm oil is added.

\section{Antinutritional Factors}

Foods are complex substances that contain many chemical compounds, more than 50 of which are required to nourish the body. These nutrients include water, protein, lipid, carbohydrate, minerals and vitamins. Most plant foods consist of natural co mpounds or anti-nutrients that appear to function generally in defense against herbivores and pathogens. Anti-nutrients are potentially harmful and give rise to a genuine concern for human and animal health in that they prevent digestion and absorption of nutrients. They may not be toxic as such, but can reduce the nutritional value of a plant by causing a deficiency in essential nutrients or preventing thorough digestion when consumed[14]. The most commonly known and studied anti-nutritional factors in roots and tubers include cyanogenic glycosides, saponin, phytate, o xalate, en zy me inhibitors and total alka loids (Tab le 3 ). They must be inactivated or removed before they are suitable for non ruminants or fish.[15, 16].

The cyanogenic glycosides or cyanogens are glycosides of 2-hydro xynitriles that are synthesized and stored in cassava and are widely distributed among plants [17, 18]. The peel component has the highest concentrations of cyanogenic glycosides in cassava (Table 3). In cocoyam tubers, Abdulrashid and Agwunobi[11], Olajide, et al[13] reported wide variation $(2.10-17.13 \mathrm{mg} / 100 \mathrm{~g})$ in the level of these undes irable substances. Hydrolys is of cyanogenic glycosides releases hydrogen cyanide $(\mathrm{HCN})$, which inhibit several enzyme systems, depress growth through interference with certain essential amino acids and utilization of associated nutrients[2, 21]. Cytochrome oxidase, is the primary site of action for ingested cyanide, an effective inhibitor of many metalloen zy mes[22].

The enzyme cytochrome oxidase in the mitochondria of cells is inactivated by hydrogen cyanide binding to the $\mathrm{Fe}^{2+}$ / $\mathrm{Fe}^{3+}$ contained in the enzyme. This results in a reduction of oxygen usage in the tissues[23] and oxygen starvation at cellular level, due to the effects of cyanide poisoning, resulting in death. Respiratory failure is therefore the cause of death since the respiratory centre nerve cells are ext remely sensitive to hypoxia[24]. Other diseases associated with dietary cyanide intake include (i) konzo (Cliff et al 1997), a paralytic disease; (ii) tropical ataxic neuropathy (TAN)[25], a nerve-damaging disorder that renders a person unsteady and uncoordinated; (iii) goiter and cretinism[26]. Sheeba and Padmaja[21] observed that the palatability and shelf-life of cassava products may be prolonged by processing. The levels of cyanogenic glycosides and hydrogen cyanide are also reduced to safer limits by processing (peeling, slicing, boiling, fermentation) before consumption $[27,28]$. 
Table 2. Composition of roots, tubers, their by-products and cereals (\% dry matter)

\begin{tabular}{|c|c|c|c|c|c|c|c|}
\hline & Dry matter & $\begin{array}{l}\text { Crude } \\
\text { protein }\end{array}$ & Crude fibre & Fat & Ash & Starch & $\begin{array}{l}\text { Gross energy } \\
(\mathrm{kcal} / \mathrm{kg})\end{array}$ \\
\hline \multicolumn{8}{|l|}{ Roots and tubers } \\
\hline Cassava Root & 31.90 & 2.70 & 3.10 & 0.80 & 3.70 & 76.5 & 3909.40 \\
\hline $\begin{array}{l}\text { Cassava Root } \\
\text { (ensiled) }\end{array}$ & 34.50 & 2.00 & 2.90 & 0.50 & 3.4 & 74.10 & \multirow{2}{*}{$\begin{array}{l}3010.18 \\
4061.00\end{array}$} \\
\hline Sweet Potato Tuber & 30.10 & 2.50 & 1.53 & 0.60 & 1.0 & 72.40 & \\
\hline Coco Yam Tuber & 24.90 & 7.90 & 1.90 & 0.70 & 5.20 & 77.9 & 3474.60 \\
\hline \multicolumn{8}{|c|}{ Root and tuber by-products } \\
\hline Cassava Peel (dry) & 94.90 & 8.20 & 12.50 & 3.10 & 5.40 & - & 2460.00 \\
\hline $\begin{array}{c}\text { Cassava Leaves } \\
\text { (dry) }\end{array}$ & 92.20 & 29.00 & 14.90 & 6.70 & 11.6 & - & 2532.37 \\
\hline $\begin{array}{c}\text { Sweet Potato Vines } \\
\text { (dry) }\end{array}$ & 86.60 & 23.10 & 16.00 & 5.30 & 4.02 & - & 2269.58 \\
\hline $\begin{array}{c}\text { Coco Yam Leaves } \\
\text { Cereals }\end{array}$ & 8.20 & 20.60 & 12.10 & 11.70 & 12.10 & - & 2314.60 \\
\hline Maize & 87.0 & 10.0 & 1.3 & 4.0 & 2.0 & 71.8 & 4096.5 \\
\hline Guinea corn & 88.4 & 9.9 & 2.9 & 2.4 & 2.1 & 74.6 & 3940.9 \\
\hline
\end{tabular}

Source: $[8-13]$

Table 3. Symptoms and mode of elimination of toxic components of Roots, Tubers and their by-products

\begin{tabular}{|c|c|c|c|c|}
\hline $\begin{array}{l}\text { Roots, T ubers and } \\
\text { by-products }\end{array}$ & $\begin{array}{l}\text { Toxic/Anti-nutritional } \\
\text { factor }\end{array}$ & Typical levels & $\begin{array}{c}\text { Primary associated } \\
\text { symptoms }\end{array}$ & Mode of elimination \\
\hline Fresh cassava root & Hydrocyanic acid & $233-1150(\mathrm{mg} / \mathrm{kg} \mathrm{Dm})$ & $\begin{array}{l}\text { Vomiting, dizziness, } \\
\text { weakness, diarrhoea, death }\end{array}$ & $\begin{array}{l}\text { Fermentation, boiling, } \\
\text { grat ing cooking, ensiling, } \\
\text { sun-drying }\end{array}$ \\
\hline Fresh cassava peel & Ditto & $1300-2250(\mathrm{mg} / \mathrm{kg} \mathrm{Dm})$ & Ditto & Ditto \\
\hline Dried cassava root & Ditto & $14-65(\mathrm{mg} / \mathrm{kg} \mathrm{Dm})$ & Ditto & Ditto \\
\hline Dried cassava waste & Ditto & $57.2(\mathrm{mg} / \mathrm{kg} \mathrm{Dm})$ & \multirow{6}{*}{$\begin{array}{c}\text { Irritation/burning } \\
\text { sensation } \\
\text { Precipitation of calcium, } \\
\text { int erference with mineral } \\
\text { absorption } \\
\text { Bitter taste } \\
\text { Impairment of } \\
\text { proteolytic digestion }\end{array}$} & \multirow{5}{*}{$\begin{array}{l}\text { Cooking, heating and } \\
\text { fermentation }\end{array}$} \\
\hline Fresh cassava leaves & Ditto & $2650-7200(\mathrm{mg} / \mathrm{kg} \mathrm{Dm})$ & & \\
\hline Cocoyam tuber & $\begin{array}{l}\text { irritat ing/acridity } \\
\text { substance }\end{array}$ & 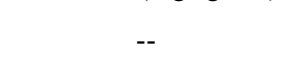 & & \\
\hline & oxalic acid & $45.3(\mathrm{~g} / 100 \mathrm{~g} \mathrm{Dm})$ & & \\
\hline & Saponin & $0.53-7.9 \quad(\mathrm{~g} / 100 \mathrm{~g} \mathrm{Dm})$ & & \\
\hline Sweet potato & Trypsin Inhibitor & 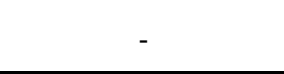 & & cooking \\
\hline
\end{tabular}

Source:[8, 13, 19, 20]

Phytic acid, which is hexaphosphate of myo-inositol, is very common in the plant kingdom[29]. Phytic acid is the primary storage compound of phosphorus in plants, accounting for up to 80 per cent of the total phosphorus[30, 31]. Phytic acid has been found in cassava root[32] and cocoyam tuber[13] up to levels of 62.4 and $1.75 \mathrm{~g} / 100 \mathrm{~g}$, respectively. Josefsen et al.,[33] reported that the negatively charged phosphate in phytic acid strongly binds to metallic cations (e.g. $\mathrm{Ca}, \mathrm{Fe}, \mathrm{K}, \mathrm{Mg}, \mathrm{Mn}$ and $\mathrm{Zn}$ ) and forms a mixed salt called phytin or phytate.

Phytate forms insoluble complexes because they are negatively charged under physiological conditions. These complexes cannot be digested or absorbed in the gastrointestinal tract of monogastric animals owing to the absence of the intestinal phytase enzyme [34]. Deficiencies of phosphorus and nutritionally important minerals in monogastric animals can be a result of cations bound in the phytic acid salt and of low bioavailability of phosphorus [35, 36]

The plant oxalis, commonly known as wood sorrel, gave rise to oxalic acid, a strong, organic acid which has been found to be widely distributed in plants[37]. Up to $45.30 \mathrm{~g} / 100 \mathrm{~g}$ has been found in cocoyam tuber[13]. Strong bonds are formed between oxalic acid and various other minerals, such as calcium, magnesium, sodium and potassium[38, 39].

The plant oxalis, common ly known as wood sorrel, gave rise to oxalic acid, a strong, organic acid which has been found to be widely distributed in plants[37]. Up to $45.30 \mathrm{~g} / 100 \mathrm{~g}$ has been found in cocoyam tuber[13]. Strong bonds are formed between oxalic acid and various other minerals, such as calcium, magnesium, sodium and potassium[38, 39].

This chemical combination results in the formation of oxalate salts. A salt formed fromoxalic acid is known as an oxalate: for example, calcium oxalate. Some oxalate salts, such as sodium and potassium, are soluble, whereas calcium oxalate salts are basically insoluble. The insoluble calcium oxalate has the tendency to precipitate (or solidify) in the kidneys or in the urinary tract, thus forming sharp-edged calciu m oxalate crystals when the levels are high enough [40]. These crystals play a role in the formation of kidney 
stones[39]. When oxalic acid is consumed, it irritates the lining of the gut and can prove fatal in large doses. Most taro cultivars have an astringent taste and can cause swelling of lips, mouth and throat if eaten unprocessed. This is caused by closely-packed, needle-like, calc ium oxalate crystals, which can penetrate soft skin[40]. Both the tubers and the leaves can give this reaction[41] but this effect is reduced by cooking[40].

\section{Use of Cassava in Diets for Poultry}

Poultry feed constitutes more than 90 percent of all commercial livestock feeds produced. The use of cassava as a substitute for maize will therefore make its greatest impact if it can be incorporated into commercial poultry feeds. Certain precautions need to be taken to achieve satisfactory performance of stock on cassava-based diets. These include removalo fcyanide, higher protein supplementation with fish meal, soybean, groundnut cake or methionine in its pure form and the prevention of microbial activity during sun-drying as well as overcoming dustiness. Most of the present studies indicate that satisfactory growth response has been obtained for growing chicken at $10 \%$ incorporation of cassava flour (lafun) or cassava peel into the diet; $40 \%$ inclusion of cassava flour or $20 \%$ inclusion of cassava peel in layer's diet is satisfactory for egg production[2]. Combination of cassava root and leaves in ratio 4:1 could replace maize in poultry diets and reduce feed cost without a loss in weight gain or egg production[42]. Feeding cassava chips supplemented with Moringa oleifera leaf meal at 5 and $10 \%$ levels showed that cassava chips replacing maize at 55.56 and $83.33 \%$ in the diets of broilers has no negative effect on productivity and haematology when 5\% Moringa oleifera leaf meal was added[43].

\section{Use of Cassava in Diets for Pigs}

Cassava can be fed to pigs either fresh or parboiled (as commonly practice in s mall and medium scale pig farms), or included in the diets as a dried meal. Due to high level of mo isture, fresh cassava is not recommended for feeding suckling and weaned pigs. Also, in starter pig diet, cassava meal should be limited because of the potential problems with palatability and its powdery nature which can affect respiratory organs. This can be overcome by pelleting. The use of cassava peels as a partial replacement for maize in young pig diets was cost effective and up to a $57 \%$ level of inclusion had no deleterious effect on the pigs [44]. Reports on growing-finishing pigs fed diets supplemented with groundnut cake, fish meal and brewer's dried gra ins in which cassava meal or cassava peel substituted $60 \%$ or $100 \%$ of the maize respectively, showed no decline/adverse effects on performance and the economics of replacing maize with cassava or its by-product will depend on the price of protein supplementation that can provide an adequate margin of profit[45]. The authors concluded that $40 \%$ inclusion of cassava into growing pig diet was economically feasible. Ospina et al[46] found that pigs fed cassava root meal ad libitum, combined with $200 \mathrm{~g} /$ day of crude protein throughout the growing-fin ishing period gave acceptable growth performance and carcass quality.

\section{Use of Cassava in Diets for Fish}

The starch in cassava is highly digestible when compared to that of maize due to the high content of amy lopectin[47]. Cassava can therefore be used as a source of energy in fish feed, but attention should be paid to the low protein, metabolizable energy and hydrogen cyanide $(\mathrm{HCN})$ contents in cassava products. Studies on the use of cassava meal in fish feed[48 - 50] indicate that cassava can replace the conventional energy feed ingredients such as maize, broken rice and sorghum, which are commonly used in animal diet in most parts of Africa[51]. Cassava has been successfully used to replace maize in Clarias gariepinus fingerlings - 50\% replacement[3]; C. garieipinus advanced fry[52] and hybrid catfish (Hetero X Clarias) - 66\% replacement[53]. Inclusion of whole cassava root meal in the diet of fish enhanced growth and survival. Hence fish farmers can therefore take advantage of this ingredient as a replacement for more expensive maize when formulating feed for fish in aquaculture.

\section{Use of Cassava Peel in Poultry Diets}

Cassava peel can be used to cut down the cost of production and lead to an active and sustainable development in livestock production[54]. So me workers [55 -57] recommended the inclusion of fermented cassava peel up to $15 \%$ in broiler diets with no adverse effects. For a reasonable performance of animals fed cassava-based diets, the rations must be nutritionally balanced and with protein source that contain sufficient sulphur-containing amino acids[58].

In the study on the influence of protein source on the performance and haematology of broiler chicken on cassava peel-based diets using fishmeal and groundnut cake, Egbunike et al[59] reported that broilers could be raised on cassava peel-based diets using groundnut cake as protein source without any adverse effect on performance indices. Also, Sogunle et al[60] studied the inclusion cashew nut reject and cassava peel meal in the diet of growing pullets and concluded that combination of $10 \%$ cassava peel meal and $30 \%$ cashew nut reject meal was appropriate for enhanced performance of growing pullets.

\section{Potentials and Limitations of Cassava Leaves as Non-Ruminant Animal Feed}


Cassava, one of the world top calorie producers for human consumption, is generally grown without fertilization on soils with poor fertility and can survive prolonged water deficit[61], it is tolerant to acid soils, but the yield is limited by poor phosphorus (P) supply[62]. Cassava is planted mostly for its tuberous root, leaving the leaves to wither after harvesting the root. However, it is possible to obtain from cassava leaves more than 6 tonnes of crude protein ha $^{-1}$ year $^{-1}$ with proper agronomic practices directed toward foliage harvesting[5].

Cassava leaf contains high level of crude protein, vitamins and nutritionally valuable minerals $[63,64]$. The nutritional limitations of cassava leave include the HCN content, low digestible energy, bulkiness and possibly the high tannin content[65]. The inherent cyanogenetic glycosides may limit its use as a non ruminant feed. The cyanogenetic glycosides, is influenced by the nutritional status and age of the plant[66], and higher $\mathrm{HCN}$ levels were found in leaves fro $\mathrm{mbitter}$ than in sweeter varieties[67]. However, the HCN concentration and the bitterness associated with high cyanogenetic glycoside contents in leaves[68] decreases with the maturity of the leaves.

The two most widely used processing methods are sun drying and ensiling. In the humid tropics, especially in the wet season, sun drying is difficult and may result in the production of low quality product with severe Aspergillus and aflatoxin contamination. Ensiling the leaves entails chopping into small pieces $(2-3 \mathrm{~cm})$, then mix with additive and add common salt at $0.5 \%$ and store in sealed air tight plastic bags for two months could reduce HCN content up to $80 \%$ of the original concentrations.

In poultry it was reported that broilers could tolerate diets containing $141 \mathrm{mg}$ total cyanide $\mathrm{kg}^{-1}$ without any negative effects on growth performance[65]. According to Fasuyi and Aletor[69] cassava leaf protein concentrate can replace up to $60 \%$ fish meal without any negative effects on growth performance, haematology and serum metabolites of broiler starter. In pigs, the inclusion of $15 \%$ fresh cassava leaves in the diet had no adverse effects on the performance of growing-finishing pigs[70]. Dried or ensiled cassava leaves have been used at $16.5 \%$ and $20 \%$ respectively in the diets without significant effects on performance and carcass traits of growing pigs[71]. However, Ravindran[72] reported a depression in weight gain and feed efficiency when cassava leaf meals were included at up to $30 \%$ in diets for growing-finishing pigs. Khieu Borin et al[73] reported a significant improvement of daily weight gain of crossbred pigs fed a mixture of cassava leaves and water spinach as compared with those fed cassava leaves alone, due to increase intake and possibly the better amino acid balance of the mixture.

\section{Use of Sweet Potato by Non-Ruminant Animals}

The sweet potato, (Ipomoea batatas) belongs to the morning-glory family Convolvuceace. It is cultivated primarily in tropical areas and ranked fifth among the most important food crop in the tropics[74]. The cost of production of sweet potato is much lower compared to cereal crops[75]. The carbohydrates of sweet potato are highly available and can be greatly utilized by non-ruminant animals [76]. Also, patatin which accounts for $30-40 \%$ of protein in the potato tuber is extremely well balanced, being nutritionally similar to casein[77].

The leave meal has a high protein content of between 26 to $33 \%$, with high amino acid score. It has good mineral profile and rich in vitamins like $\mathrm{A}, \mathrm{B}_{2}, \mathrm{C}$ and $\mathrm{E}$. Apart from its nutritive values, sweet potato leaves can be harvested many times throughout the year[78] thereby making the leaf meal to be abundant. The major factor limiting its use in monogastric animal is the presence of anti-nutritional factors[79]. The antinutritional substances present in the sweet potato leaves, according to Oyenuga[10], are the protease inhibitors and invertase. These substances can be inactivated by various processing methods like oven or sun-drying, boiling or steaming and grinding prior to inclusion in animal feeds.

With regard to non-ruminant feeding, the data on sweet potato are limited. However, reports by Yeh and Bouwkamp[80] and Nwokolo[81] showed that up to $50 \%$ of the grain in corn-soybean diets could be replaced with sweet potato chips, without a significant depression in growth or production. With such high levels of replacement, it may be necessary to supplement such sweet potato - based diets with $0.2-0.5 \%$ of lysine. The dustiness of the sweet potato and high content of reducing sugars will tend to limit its use at such high levels in poultry and other non-ruminant ruminant diets [82].

Inclusion of sweet potato leaf meal in the diet of Tilapia zilli showed that levels up to $15 \%$ could be added without any negative effects on the growth, feed efficiency and protein digestibility[83]. In the same vein, Omoregie et al[84] revealed that Oreochromis niloticus could tolerate up to $15 \%$ level of inclusion of sweet potato peel.

\section{Use of Cocoyam in Diets for Poultry}

Cocoyam is recognized as cheaper carbohydrate sources than grains or other tuber crops [85]. It has high caloric yield per hectare, low production cost[86] and relatively low susceptibility to insect and pest attack. Similarly, it is reported that cocoyam has readily digestible starch content because of its small particle size[87, 88]. It is almost competition-free with man in most places as it is eaten only as a last resort when a family can no longer afford garri or yam. It is therefore more likely to be available for use at lower cost. The use of cocoyam as food for man and animal has limiting factors such as storage and presence of antinutritional factors.

Taro is closely related to Xanthosoma and Caladium, plants commonly grown as ornamentals. The antinutritional 
factors found in taro cocoyam include oxalates, phytates, Tannins and Saponins.[4]. However, some may serve as defensive mechanism against pests and diseases. Therefore oxalates have been found to be as defense mechanism and a storage reserve for calcium[89]. There is limited reference work on the utilization and inclusion of taro cocoyam as an alternative energy source in poultry production. However, Anigbogu[90] and Abdulrashid and Agwunobi[11] reported that taro meal should not exceed $25 \%$ rep lace ment of maize in broiler diets.

Tania (Xanthosoma sagittifolium) is a high-yielding, disease resistant crop. Its energy content appears moderate when compared with maize. However, like most varieties of cocoyam, the problem with Xanthosoma sagittifolium is its content of some antinutritional factors which could be a limitation to its use[91]. Th is limiting factors can be removed by boiling or sun-drying[92].

Esonu[93] reported that starter broilers could tolerate up to $20 \%$ inclusion levels of wild variegated cocoyam (Canadium hortulanum). On the other hand, Uchegbu et al[94] showed that raw sun dried cocoyam meal can be used in the diet of fin isher broilers up to $15 \%$ inclusion level without being detrimental to their performance. However, $10 \%$ cocoyam inclusion level is the best in terms of daily weight gain, feed conversion ratio, and cost effectiveness.

Wild cocoyam is a high moisture tuberous rootstock. Presently, it is not directly consumed by man and equally of no industrial use. Available literature on the feeding of wild cocoyam meals to finisher broilers suggests that it is a satisfactory energy ingredient at up to $20 \%$ of the whole ration $[95,96]$. However, its liberal use in monogastric animal feeding could be encumbered by the presence of some anti-nutritional factors (tannin and trypsin inhibitor), which adversely affect protein and energy utilization in broilers[96, 97]. The use of heat to inactivate these anti-nutritional factors could increase the use of wild cocoyam as a feed component in broiler diets.

\section{Use of Cocoyam in Diets for Pigs}

Cocoyam corms intended for utilization as pig feed need to be cooked prior to drying and feeding to ensure removalof the toxic substance (oxalic acid) present in the corms, leaves and petiole of the plant. There are few actual experiments conducted on cocoyam utilization. However, it is recommended that cooked dried cocoyamcan be fed on sows in gestation and late lactation but not to starter pigs or those in the early grower phase. Cocoyamsilage may be fed to pigs in the growing and fattening stages, as well as to gilts in gestation and lactation. At levels of $20-40 \%$ of dry matter, cocoyam silage supported adequate growth rate in young pigs[93]. Ohaemenyi[98] reported that Xanthosoma sagittifolium corms can be cooked and used to some extent in the diets of growing pigs.

\section{Conclusions}

Considering the chemical and nutritional characteristics of available alternative energy supplements (roots, tubers and their by-products), they have potential for increase use as alternative energy supplements for non ruminant production. Furthermore, these materials possess readily digestible energy.

The comparable growth performance of pigs and poultry fed varying levels of roots, tubers and their by-products with those fed maize showed that they can be used as substitutes in non-ruminants diet at certain levels without being detrimental to their performance. However, for improved performance of animals, rations containing roots, tubers or their by-products must be formu lated to contain good protein source and sufficient sulphur-containing amino acids. In addition, various processing methods (e.g. drying, boiling, frying, fermentation and ensiling) can be employed to eliminate or reduce the anti-nutritional factors present; this will improve the quality and safety of these feed materials. If these findings are diffused and adopted by farmers and livestock feed manufacturers, the amount of roots and tubers used in non-ruminant feed production in Nigeria would increase with consequent reduction in pressure on demand for cereal grains.

\section{REFERENCES}

[1] Tewe O O. "Sustainability and Development Paradigms from Nigerian Liv estock Industry". Inaugral Lecture, University of Ibadan Nigeria, 1997.

[2] Tewe O O and Egbunike G N. "Utilization of cassava in non-ruminant feeding" In: Cassava as Livestock Feed in Africa (S.K. Hahn, L. Reynoids and G.N. Egbunike, eds.). IITA, Ibadan and ILCA. Addis Ababa. p. 28-38, 1992.

[3] Olurin K B, Olujo E A A and Olukoya O A. "Growth of African catfish Clarias gariepinus fingerlings, fed different levels of cassava" World Journal of Zoology (1):54-56, 2006.

[4] Agwunobi L N, Angwukam P O, Cora O O and Isika M A. "Studies on the use of Coweosia esculenta (Taro cocoyam) in the diets of weaned pigs" Tropical Animal Health and Production 34: 244 - 47, 2002.

[5] AFRIS. "Animal Feed Resources Information Systems" Updated from B. Gohl (1981) Tropical Feeds. Food and Agriculture Organization. http://www.fao.org./ag/AGa/agap/ FRG/AFRIS/DATA/535.htm., 2004

[6] FAO "Food outlook. Food and Agriculture Organisation Corporate Document Repository" http://www.fao.org/docrep /012/ak341e/ak341e06.htm, 2009.

[7] Longe O G. "Poultry: Treasure in a chest" Inaugural Lecture, University of Ibadan, Nigeria, 2006.

[8] Apata D F, Joseph J K and Adeoye E O. "Performance, blood composition and carcass quality attributes of rabbits fed dietary levels of cassava and yam wastes" Nig. Journal of Pure and Applied Science 15: 234-239, 1999

[9] Bradbury J and Nixon R. "The acridity of raphides from the 
edible aroids" Journal of the Science of Food and Agriculture 76: $608-616,1998$.

[10] Oyenuga V A. "Nigeria's foods and feeding stuffs" Ibadan University Press, pp: 20-25, 1968.

[11] Abdulrashid $M$ and Agwunobi L N. "Taro cocoyam (Colocasia esculenta) meal as feed ingredient in poultry". Pakistan Journal of Nutrition 8: 666 - 673, 2009.

[12] Harvey D. "Tables of the amino acids in foods and feeding stuffs" $3^{\text {rd }}$ edition. Commonwealth Bureau of Animal Nutrition, Farham Royal, Bucks, England, 1980.

[13] Olajide R, Akinsoyinu A O, Babayemi O J, Omojola A B, $\mathrm{Abu} \mathrm{A} \mathrm{O}$ and Afolabi K D. "Effect of processing on energy value, nutrient and anti-nutrient components of wild cocoyam (Colocosia esculenta (L.) Scchot) corm" Pakistan Journal of Nutrition 10: 29 - 34, 2011.

[14] Prathibha S, Nambisan B and Leelarnma S. "Enzyme inhibitors in tuber crops and their thermal stability" Plant Foods for Human Nutrition 48: 247 - 257, 1995.

[15] Bhandari M R and Kawabata J. "Assessment of antinutritional factors and bioavailability of calcium and zinc in wild yam (Dioscorea spp) tubers of Nepal" Food Chemistry 85: $281-287,2004$.

[16] Agbor-Egbe T and Mbome L. "The effects of processing techniques in reducing cyanogens levels during the production of some Cameroonian cassava foods" Journal of Food Composition and Analysis 19: 354 - 363, 2006.

[17] Rosenthal G A and Berenbaum M R. "Herbivores - Their interactions with secondary plant metabolites" Academic Press, New York. pp. 199-270, 1991.

[18] Bisby F A, Buckingham J and Harbome J B. "Phytochemical Dictionary of the Fabaceae. Plants and their Constituents" Vol. 1, Chapman and Hall, London. p 357, 1994.

[19] Nwokolo E. "Cocoyams" In: Nontraditional feed sources for use in swine production. Eds. Thacker. P.A. and Kirk Wood, R.N. Butterwort Publishers, USA. pp. 113-122, 1990a.

[20] Tewe O O, Job T A, Loosli J K and Oyenuga V A. "Composition of two local cassava varieties and the effect of processing on their hydrocyanic acid content and nutrient digestibility by the rat" Nigeria Journal of Animal Production 3:60-66, 1976.

[21] Okafor P N. "Assessment of cyanide overload in cassava consuming populations of Nigeria and the cyanide content of some cassava based foods" African Journal of Biotechnology 3, 358-361, 2004.

[22] Enneking D and Wink M. "Towards the elimination of anti-nutritional factors in grain legumes" In: Knight, R. (Ed.), Linking Research and Marketing Opportunities for Pulses in the 21st Century. Kluwer Academic Publishers, Dordrecht/Boston/London, pp. 671-683, 2000.

[23] Vetter I. "Plant cyanogenic gly cosides". Toxicon 38, 11-36, 2000.

[24] Okolie N P and Osagie A D. "Liver and kiduey lesions and associated enzyme changes induced in rabbits by chronic cyanide exposure" Food Chemistry Toxicology 37,745-750, 1999.

[25] Onabolu A O, Oluwole O S A, Bokanga M and Rosling H.
"Ecological variation of intake of cassava food and dietary cyanide load in Nigerian communities" Public Health Nutrition 4, 871-876, 2001.

[26] Delange F, Ekpechi L O and Rosling H. "Cassava cyanogenesis and iodine deficiency disorders" Acta Horticulturae 375: 289 - 293, 1994.

[27] Sheeba R and Padmaja G. "Mechanism of cyanogenic reduction" Journal of the. Science of Food and Agriculture 75, 427-432, 1997.

[28] Feng D, Shen Y and Chavez E R. "Effectiveness of different processing methods in reducing hydrogen cyanide content of flaxseed" Journal of the Science of Food and Agriculture 83: $836-841,2003$.

[29] Chan S S L, Fergnson E L, Bailey K, Falnnida U, Harper T B and Gibson R S. "The concentrations of iron, calcium, zinc and phytate in cereals and legumes habitually consumed by infants living in East Lombok, Indonesia" Journal of Food Composition and Analysis 20: 609 - 617, 2007.

[30] Raboy V. "Seed for a better future: 'low phytate' grains help to overcome malnutrition and reduce pollution". Trends in Plant Science 6, 458-462, 2001.

[31] Steiner T, Mosenthin R., Zimmerman B, Greiner R and Roth S. "Distribution of phytase activity, total phosphorus and phytate phosphorus in legume seeds, cereals and cereal by-products as influenced by harvest year and cultivar" Animal Feed Science and Technology 133: 320 - 334, 2007.

[32] Panigrahi S, Rickard J, O'Brien G M and Gay C. "Effects of different rates of drying cassava root in its toxicity to broiler chicks" British Poultry Science 33, 1025-1041, 1992.

[33] Josefsen L, Bohn L, Smenson M B and Rasmussen S K. "Characterization of a multifunctional inositol phosphate kinase from rice and barley belonging to the ATPgrasp superfamily". Gene 397: 114 - 125, 2007.

[34] Iqbal T H, Lewis K O and Cooper B T. "Phytase activity in the human and rat small intestine". Gut 35: 1233 - 1236, 1994.

[35] Apata D F and Ologbobo A D. "Influence of phytic acid on the availability of minerals from selected tropical legume seeds" Nigerian Journal of Science 88 - 91, 1989.

[36] Gibson R S, Perlas L and Hotz C. "Improving the bioavailability of nutrients in plant foods at the household level" Proceedings of the Nutrition Society 65: 160 - 168, 2006.

[37] Liebman M. "The truth about oxalate: answers to frequently asked questions". The Vulvar Pain Newsletter, no. 22[online]. Available from: $<$ httpJ1_www.vulvarpainfoundation.org/vp $\mathrm{f}$ newsletteLhtm>, 2002.[A-ccessed 20 May 2011].

[38] Fink S. "The micromorphological distribution of bound calcium in needles of Norway spruce" (Picea abies (L.) Karst.). New Phytologist 119: 33 - 40, 1991.

[39] Noonan S C and Savage G P. "Oxalate content of food and its effect on humans" Asia- Pacific Journal of Clinical Nutrition 8: $64-74,1999$.

[40] Bradbury J A."Chemical composition of Tropical Root crops and its implication for nutritional" Sweet potato Proc. $8^{\text {th }}$ Int. Symp. Pp. 159-170, 1988.

[41] FAO 1992 Taro: a South Pacific speciality. Leaflet - revised 
1992. Community Health Services, South Pacific Commission, B.P. D5 Noumea, Cedex, New Caledonia.

[42] Tewe O O and Bokanga M. Research highlights cassava utilization. International Institute of Tropical Agriculture, Ibadan, Nigeria, 2001.

[43] Olugbemi T S, Mutayoba S K and Lekule F P. "Effect of Moringa (Moringa oleifera) inclusion in cassava based diets fed to broiler chickens" International Journal of Poultry Science 9: 363 - 367, 2010.

[44] Balogun T F and Bawa G S. "Cassava peels in the diet of young pigs in Nigeria". Tropical Animal Health and Production 29:209-215, 1997.

[45] Sonaiya E B and Omole T A. "Cassava meal and cassava peel meal in diets for growing pigs" Animal Feed Science and Technology 8:211-220, 1983.

[46] Ospina L, Preston T R and Ogle B. "Effect of protein supply in cassava root meal based diets on the performance of growing-fin ishing pigs" LRRD 7 (2). Retrieved July 26,2011, from http://www.irrd.org/irrd15/7/chha157.htm., 1995.

[47] Talthawan B E, Lic O and Froyland L. "Lipid metabolism and tissue composition in Atlantic Salmon (Salmo salar) effects of capelin oil, palm oil and oleic enriched sunflower oil as dietary lipid sources" Lipids 35:653- 664, 2002.

[48] Oresegun A and Alegbeleye W O. "Serum and tissue thiocy anate concentration in Tilapia (Oreochromis niloticus) fed cassava peel based diets supplemented with DL-M ethionine" Journal of Aquaculture in the Tropics 17(2): 93-100, 2002.

[49] Faturoti E O, Balogun A M and Ugwu L L C. "Nutrient utilization and growth responses of clarias (Clarias lazera) fed different dietary protein levels" Nigeria Journal of Applied Fish Hydrobiology $1: 41-45,2002$.

[50] Eyo A A. "Fundamentals of fish nutrition and diet development" in: A. A. Eyo (eds) National workshop on fish feed development and feeding practices. 80pp, 2003.

[51] Akinfala E O and Tewe O O. "Utilization of whole cassava plant in the diets of growing pigs in the tropics" Livestock Research for Rural Development. 13:5-12, 2001.

[52] Olukunle O. "Nutritive potential of sweet potato peel meal and root replacement value for maize in diets of Africa catfish (Clarias gariepinus) advanced fry" Journal of Food Technology 4(4):289-293, 2006.

[53] Abu O M G, Gabriel U U and Akinrotimi O A. "Performance and survival of hybrid catfish (Hetero X Clarias) fed with whole cassava root meal as a replacement for maize" Journal of Tropical Agriculture Environment and Extension 9: $176-$ $183,2010$.

[54] Olorede B R, Sadu Y, Abdurahim I, Ajagbonna O P and Akinloye O A. "Blood chemistry and histopathology of cockerel fed cassava flour" ASAN proceedings, pp: 38-40, 2002.

[55] Osei S A and Duodu S. "Effects of fermented cassava peel meal on the performance of broilers" British Poultry Science, 29: 671-675, 1998.

[56] Agunbiade J A, Adeyemi O A, Fasina O E and Bagbe S A. "Fortification of cassava peel meal in balanced diets for rabbits" Nigeria Journal of Animal Production, 28: 167 - 173, 2001.
[57] Salami R I, Ogunmola A L and. Akindoye O. "Cassava peel processed by different methods as substitute for maize in cockerel starter diets". Proc. 28th Ann. Conference of Nigeria Society of Animal Production, 16 - 20 March. Ibadan. p. 177-179, 2003.

[58] Tewe O O. "Detoxification of cassava products and effects of residual toxins on consuming animals. In: Roots, tubers, plantains and bananas in animal feeding" Proc. FAO expert consultation, CIAT, Cali, Columbia, 21-25 January. 1991. p. 81-89, 1992.

[59] Egbunike G N, Agiang E A, Owosibo A O and Fatufe A A. "Effect of protein on performance and haematology of broilers fed cassava peel-based diets" Archivo Zootechnical 58: $655-662,2009$.

[60] Sogunle O M, Fanimo A O, Abiola S S and Bamgbose A M. "Performance of growing pullets fed cassava peel meal diet supplemented with cashew nut reject meal" Archivo. Zootechnical. 221:23 - 31, 2009.

[61] Alves A A C and Setter T L. "Response of cassava to water deficit: Leaf area growth and abscisic acid" Crop Science 40, 131-137, 2000.

[62] Howeler R H. "Mineral nutrition and fertilization of cassava" In Cassava: Research, Production and Utilization, J.H. Cock and J.A. Reyes (Eds.). UNDP/CIAT, Cali, Columbia. pp. 249-320, 1985 .

[63] Rogers D J and Milner M. "Amino acids profile of manioc leaf protein in relation to nutritive value" Economic Botany $17,211-216,1963$

[64] Aletor V A and Adeogun O A. "Nutrients and anti-nutrients components of some tropical leafy vegetables" Food Chemistry 54: 375 - 379, 1995.

[65] Ravindran V, Kormegay E T, Rajaguru A S B, Potter L M and Cherry J A. "Cassava leaf meal as replacement for coconut oil meal in broiler diets" Poultry Science 65, 1720-1727, 1986.

[66] Ravindran V and Ravindran G."Changes in the nutritional composition of cassava (Manihot esculenta Crantz) levels during maturity" Food chemistry, 27: 229 - 239, 1988.

[67] Tewe O O and Iyayi E A. "Cyanogenic glycosides" In Toxicants of plant origin, Vol. II, Glycosides, P.R. Cheeke (ed.) pp. 43-60. CRS Press, 1989.

[68] Sundaresan S, Amma C S E and Nambisan B. "Bitterness in cassava in relation to cy anoglucoside content" Indian Journal of Agric Science 57, 37-40, 1987.

[69] Fasuyi A O and Aletor V A. "Protein replacement value of cassava (Manihot esculenta, Crantz) leaf protein concentrate in broiler starter: effect on performance, muscle growth, haematology and serum metabolites" International Journal of Poultry Science 4: 339 - 349, 2005.

[70] Sarwat S V, Kakala S N and Kategile J A. "Performance of growing finishing pigs when fed diets containing fresh cassava leaves and roots" East African Agriculture and Forestry Journal 53, 111-115, 1988

[71] Nguyen T H, Le D N, Martin W A V and Wouter H H. "Ensiled and dry cassava leaves, and sweet potato vines as a protein source in diets for growing Vietnamese Large White $\mathrm{x}$ Mong Cai pigs" Asian-Australian Journal of Animal Science 23: 1205-1212, 2010.

[72] Ravindran V. "Feeding value and digestibility of cassava leaf 
meals for growingpigs" Proceedings Fifth Asian Australasian Animal Production Congress. Volume 3: 20, 1990.

[73] Khieu Borin 2005 Cassava foliage for monogastric animals. Doctoral diss. Dept. of Animal Nutrition and Management, SLU. Acta Universitatis agriculturae Sueciae, vol. 2005, pp 82. http://diss-epsilon.slu.se/archive/00000903/, 2005.

[74] An L V. "Sweet potato leaves for growing pigs. Biomass yield, digestion and nutritive value" 2004. Doctoral Thesis, Swedish University of Agriculture Sciences Uppsala Sweden.

[75] Huarg C P. "Nutritive value of sweet potato" AVROC, 1982.

[76] Oboh S O. "Biochemical composition and utilization of sweet potato (Ipomoea batatas), in broiler rations" Ph.D thesis, University of Ibadan, Ibadan, Nigeria, 1987.

[77] Liedl B E, Kossier T and Desborough S L. "HPLC isolation and nutritional value of a major tuber proteins" American Potato. Journal, 64: 548-558, 1987.

[78] Hong $\mathrm{N} \mathrm{T} \mathrm{T,} \mathrm{Wanapat} \mathrm{M,} \mathrm{Wachirapakorn} \mathrm{C} \mathrm{P} \mathrm{K} \mathrm{and}$ Rowlinson $\mathrm{P}$. "Effect of timing of initial cutting and subsequent cutting on yields and chemical compositions of cassava hay and its supplementation on lactating dairy cows" Asian-Australian Journal of Animal Science 16: 1763 - 1769, 2003.

[79] Tacon A J. "Feed ingredients for warmwater fish and other processed feedstuffs" FAO Fisheries Circular No. 856, FAO, Rome. pp 64, 1993.

[80] Yeh T P and Bouwkamp J C. "Sweet potato roots and vines as animal feed" In: J. C. Bouwkamp, ed. Sweet Potato Products: A Natural Resource For the Tropics. CRC Press, Boca Raton, Florida, pp. 235-253, 1985.

[81] Nwokolo E. "Sweet potato In: Nontraditional feed sources for use in swine production" Eds. Thacker. P.A. and Kirk Wood, R.N. Butterwort Publishers, USA. pp. 481-489, 1990b

[82] Akinmutim, A H and Osuagwu C C. "Response of weaner rabbits fed graded levels of sweet potato meal in place of maize-based diet" Pakistan Journal of Nutrition 7: 705 - 709, 2008.

[83] Adewolu M A. "Potentials of sweet potato (Ipomea batatas) leaf meal as dietary ingredient for Tilapia zilli fingerlings" Pakistan Journal of Nutrition 7: 444 - 449, 2008.

[84] Omoregie E, Igoche L, Ojobe T O, Absalom K V and Onusiriuka B C. "Effect of varying levels of sweet potato (Ipomea batata) peels on growth, feed utilization and some biochemical responses of the Cichlid (Oreochromis niloticus)" African Journal of Food and Agriculture Nutrition and Development 9: 700 - 712, 2009.

[85] Obioha F C. "Utilisation of cassava as human feed. A literature review and research recommendation on cassava" A.I.D. csd/2497. Univ. of Georgia, pp 325, 1972

[86] Hahn S K. "Tropical root crops, their improvement and utilization. Paper presented at the conference or ganized by the Common Wealth Agric. Bureu on Advancing agricultural production in Africa" Arusha, Tanzania International Conference. (IITA), p 2, 28, 1984.

[87] Lyonga S N and Nzetchueng S. "Cocoyam and the African Food Crisis" Proceedings of the $3^{\text {rd }}$ Triennial Symposium of the International Society for tropical Root Crops-African Branch, Ibadan, Nigeria, 1986.

[88] Ezedinma F O C. "Response of Taro (Colocasia esculenta) to water management, plot preparation and population" $3^{\text {rd }}$ Intl. Symp. Trop. Root Crops, Ibadan - Nigeria, 1987.

[89] Smith D L . "Calcium oxalate and carbonate deposits in plant cells. In: The role of calcium in biology systems" L.J. Aughilori and A.M. tuffet-Anghilori (eds). CRS press, Boca Ration, FL. 253 - 261, 1982.

[90] Anigbogu M M. "Effect of Replacing Corn with Taro (Colocasia asculenta Linn) Meal on the Live weight, Dressing Percentage and Cut-up yield and Litter Condition of Broiler Chicks" Proceeding of $2^{\text {nd }}$ Annual Conference of Animal Science Association of Nigeria, Lagos. September, 1997.

[91] Okon B I, Obi M B and Ayuk A A. "Performance of quail (Coturnix coturnix Japonica) fed graded levels of boiled sun-dried taro cocoyam (Colocosa esculenta) as a replacement for maize" Agriculture Journal 2: 654 - 657, 2007.

[92] Abdulrashid M, Agwunobi L N Akpa G N and Adey inka ED. "The performance of finisher broilers on varying levels of Taro cocoyam meal" In: Proceedings of the 31st Annual Conference of Nigeria Society of Animal Production (NSAP), Kano, 2006.

[93] Esonu B O. "Animal Nutrition and Feeding: A Functional Approach" Memory Press, Oweri, Nigeria, pp. 198-204, 2000.

[94] Uchegbu M C, Etuk E B, Omede A A, Okpala C P, Okoli I C and Opara M N. "Effect of rep lacing maize with cassava root meal and maize/sorghum brewer's dried grains on the performance of starter broilers" Tropical Subtropical Agroeconomics 14: 363 - 367, 2010.

[95] Onu P N, Madubuike F N, Esonu B O and Onu D O. "The effect of wild cocoyam (Caladium bicolor) on the performance and internal organ weights of finisher broiler" Journal of Science Agriculture Food Technology and Environment 1: 19 - 24, 2001.

[96] Onu P N and Madubuike F N. "Effect of raw and cooked wild cocoyam (Caladium bicolor) on the performance of broiler chicks" Agricultura Tropica et Subtropica 39: 268 - 273, 2009.

[97] Huisman J. "Aspects of anti nutritional factors (ANFS) in relation to nutrition and pollution" Poultry Adviser 28: 57 66,1995 .

[98] Ohaemenyi C E. "A study of the corm of Xanthosoma saggitifolium (cocoyam) as a substitute for maize in the diet of young growing pigs" B.Sc. Thesis. Federal University of Technology Owerri, Nigeria, 1993. 